\title{
In vivo assessment of dog subcutaneous fat depots by real time ultrasonography and image analysis
}

\author{
Rita Payan-Carreira ${ }^{1 *}$, Luis Martins ${ }^{2}$, Sónia Miranda ${ }^{1,2,3}$, Pedro O Pinto ${ }^{2,3}$, Severiano R Silva ${ }^{1}$ \\ From Animal Obesity - causes, consequences and comparative aspects \\ Uppsala, Sweden. 14-16 June 2015
}

\section{Introduction}

Obesity is the most common nutritional disorder in dogs and a main health and welfare concern worldwide; it links to a shortened lifespan and increased rate of secondary diseases. Surveillance of dog adiposity is a routine practice and is often estimated from body condition scoring (BCS). But BCS is subjective and fairly sensitive, reducing its utility during weight-loss plans. Substitute approaches, simple, cheap and reproducible, are foreseen.

\section{Objective}

This work aimed to assess real time ultrasonography (RTU) usefulness for analysis of sub-cutaneous body fat depots (SCF) in dogs.

\section{Methods}

Twenty-eight dogs were enrolled, representing different sizes (nain-4; small-10; medium-14), weights (BW; 5.2$33.0 \mathrm{~kg})$ and BCS (2-4 in a 5 points scale). RTU images were taken with a multifrequency linear array (at $10 \mathrm{MHz}$ ) coupled to a GE scanner, from non-sedated dogs in right lateral recumbency, at five anatomical points: entry of the chest; over the ninth intercostal space; lateral abdominal wall; right inner thigh; and between the third and the fifth lumbar vertebrae. Images were analysed in Image J; means from 3-different locations per image were used to set SCF thickness. Using the JMP program correlation procedure was used to analyse SCF and BCS relationships.

\footnotetext{
* Correspondence: rtpayan@gmail.com

${ }^{1}$ Animal and Veterinary Research Center, CECAV, Universidade de Trás-osMontes e Alto Douro, Vila Real, Portugal

Full list of author information is available at the end of the article
}

\section{Results}

BW was poorly associated with SCF thickness ( $\mathrm{r}$ between $0.21, \mathrm{p}>0.05$, and $0.59, \mathrm{p}<0.01$ ), while BCS and SCF were strongly correlated ( $\mathrm{r}$ between 0.71 and 0.82 ; $\mathrm{p}<0.01$ ), particularly for data collected at lumbar and abdominal points.

\section{Conclusion}

Results stress that BW is a poor adiposity predictor and suggest that RTU is a valuable tool to predict dog adiposity.

\section{Authors' details}

${ }^{1}$ Animal and Veterinary Research Center, CECAV, Universidade de Trás-osMontes e Alto Douro, Vila Real, Portugal. Escola Universitária Vasco da Gama, Coimbra, Portugal. ${ }^{3}$ Hospital Veterinário do Baixo Vouga, Águeda, Portugal.

Published: 25 September 2015

doi:10.1186/1751-0147-57-S1-P9

Cite this article as: Payan-Carreira et al: In vivo assessment of dog subcutaneous fat depots by real time ultrasonography and image analysis. Acta Veterinaria Scandinavica 2015 57(Suppl 1):P9.

Submit your next manuscript to BioMed Central and take full advantage of:

- Convenient online submission

- Thorough peer review

- No space constraints or color figure charges

- Immediate publication on acceptance

- Inclusion in PubMed, CAS, Scopus and Google Scholar

- Research which is freely available for redistribution

Submit your manuscript at www.biomedcentral.com/submit
() Biomed Central 